\section{Incidence of hepatitis B and hepatitis C in Pediatric ward in 2ed March teaching hospital, Sebha: South of Libya}

\author{
Shaban R Bagar ${ }^{1}$, Marei A Altayar'2, Idress H Attitalla ${ }^{3,4 *}$, \\ Abdlmanam Fakron ${ }^{4}$ and Hosam B Bahnosy ${ }^{3}$ \\ 1'Department of Microbiology, Faculty of Medicine, Sirte University, Libya \\ ${ }^{2}$ Department of Microbiology, Faculty of Medicine, Benghazi University, Libya \\ ${ }^{3}$ Department of Lab Medicine and Medical Microbiology, Faculty of Medical Technology, Omar Al \\ Mukhtar University, Libya \\ ${ }^{4}$ Department of Microbiology, Faculty of Science, Omar Al Mukhtar University, Libya
}

\begin{abstract}
Objective: to determine the incidence of $\mathrm{HBV}$ and $\mathrm{HCV}$ in pediatric ward.

Sitting: 2ed March teaching hospital, sebha Libya.

Materials and Methods: this was a prospective hospital base study of pediatric cases admitted to 2ed March teaching hospital during a period from March 2018 to February 2019. Pediatric cases were studied for the incidence of HBsAg and HCV Ab by ELISA, Rapid technique. The positive result was confirmed with line immuno-assay.
\end{abstract}

Results: the study showed positive HBsAg in 12 patients and HCV in 2 cases out 25 cases represented with acute hepatitis from a total of 1763 pediatric cases were submitted in this study, with incidence rate of $0.68 \%$ and $0.11 \%$ respectively.

Conclusion: the incidence of HBV and HCV are low in Sebha, therefore active program need to be applied to control the spread of infection among the population.

\author{
More Information \\ *Address for Correspondence: \\ Idress H Attitalla, Department of Lab Medicine \\ and Medical Microbiology, Faculty of Medical \\ Technology, Omar Al Mukhtar University, Libya, \\ Email: idress.hamad@omu.edu.ly \\ Submitted: March 29, 2021 \\ Approved: April 27, 2021 \\ Published: April 28, 2021 \\ How to cite this article: Bagar SR, Altayar MA \\ Attitalla IH, Fakron A, Bahnosy HB. Incidence \\ of hepatitis $B$ and hepatitis $C$ in Pediatric ward \\ in 2ed March teaching hospital, Sebha: South \\ of Libya. Int J Clin Microbiol Biochem Technol. \\ 2021; 4: 028-031. \\ DOI: 10.29328/journal.ijcmbt.1001022 \\ Copyright: @ 2021 Bagar SR, et al. This is \\ an open access article distributed under the \\ Creative Commons Attribution License, which \\ permits unrestricted use, distribution, and \\ reproduction in any medium, provided the \\ original work is properly cited.
}

Check for updates

OPEN ACCESS

\section{Introduction}

Hepatitis B and HCV infections can lead to an acute or silent course of liver disease, progressing from liver impairment to cirrhosis and decompensated liver failure or hepatocellular carcinoma (HCC) in a 20-30 years period. In addition, HBV and HCV infection rate differ in different settings, and prognosis may be worse in conjunction with schistosomiasis in Egypt, malaria in Sudan, and HIV in other African populations [1].

Viral hepatitis caused by HCV and HBV represents a major public health problem in India. These viruses share common modes of transmission, such as parenteral routes [2] Hepatitis $B$ is a viral infection of the liver and is a serious global health problem with a high risk of death from cirrhosis and liver cancer, a disease that killed about one million persons each year. Globally, of the two billion people who have been infected with HBV more than 350 million have a chronic infection [3].
HBV is endemic in Senegal. According to many data, the prevalence of this infection in the adult population is up to $85 \%$. Young children are a victim of the intensive circulation of this virus. Indeed, the risk of becoming a chronic carrier which can further lead to HCC is related to the age at which the infection had been contracted [4].

A growing body of evidence indicates that HIV positive individuals are more likely to be infected with HBV than HIV negative individuals, possibly as a result of shared risk factors. There is also evidence that HIV positive individuals who are subsequently infected with HBV are more likely to become HBV chronic carriers, have a high HBV replication rate with HBeAg positive for a much longer period. In addition, it is evident that immunosuppression brought about by HIV infection may cause reactivation or reinfection in those previously exposed to HBV. Furthermore, HIV infection exacerbates liver disease 
in HBV co-infected individuals, and there is an even greater risk of liver disease when HIV and HBV co-infected patients are treated with highly active antiretroviral therapy (HAART) [5]. The tropical features of HCV have not yet been fully elucidated due to the scarcity of data. However, it has been estimated that two-thirds of the infected population lives in the tropics. The most heavily affected regions are Africa, China and South East Asia with a prevalence rate of 5.3\%, 3.0\% and 2.4\% respectively. In several countries mostly in Africa, prevalence rates range from $5 \%$ to $10 \%$ or higher [6]. The outcome of HCV infection acquired in childhood is uncertain because of the diversity of the epidemiological and clinical features of infection and disease [7]. The natural history of HCV infection has a highly variable course. Many patients develop chronic infection, with the consequent risk of cirrhosis, liver failure and HCC. The disease progression is influenced by certain factors such as duration of infection, age, sex, co-infection with HBV, EBV, CMV. The level of HCV viremia and its type. Other endemic infections in the community as bilharziasis may have a role in the progression of the condition to serious complication. These factors are correlated with newly proposed grades and stages of the disease [8].

\section{Result}

A total of 1877 pediatric cases admitted to the hospital during a period from March 2018 to February 2019. From the total admission, only 25 cases $(1.3 \%)$ were presented with clinical hepatitis (jaundice, hepatomegaly and raised liver enzymes). All 25 cases further tested for HBsAg as well as HCV antibody. There were 12 cases of positive HBV $(0.65)$ of the total admission and (48\%) of the hepatitis cases, of these 6 were male (50\%) and 6 female (50\%). In the case of HCV only 2 cases are found to be positive (8\%) of hepatitis cases ( 1 male and 1 female) table 1 . The distribution of HBV and HCV during the period of study shown in figure 1. While the age distribution of HBV cases shown in table 2 and the geographical distribution of acute hepatitis cases in table 3. 6 cases (50\%) out of 12 cases of HBV in the adolescent age group. 2 cases (8\%) of acute hepatitis was expired and 1 HBV and the rest were HCV infection.

\begin{tabular}{|c|c|c|c|}
\hline \multicolumn{4}{|c|}{ Table 1: Incidence of HBV and HCV in pediatric ward/months. } \\
\hline Month & Admission No & HBV & HCV \\
\hline March & 159 & 1 & \\
\hline April & 183 & 1 & 1 \\
\hline May & 162 & & \\
\hline June & 180 & 1 & \\
\hline July & 172 & 3 & \\
\hline August & 123 & 2 & \\
\hline September & 124 & & \\
\hline October & 152 & 2 & \\
\hline November & 125 & & \\
\hline December & 204 & 1 & \\
\hline January & 180 & & \\
\hline February & 111 & & \\
\hline Peak of HBV cases July-October 7 cases out of $12(58.3 \%)$. & \\
\hline \multicolumn{2}{|l|}{}
\end{tabular}

\begin{tabular}{|c|c|c|c|}
\hline Group & Age & No of patient & $\%$ \\
\hline Infant & $1 \mathrm{~m}-1$ year & 1 & 8.33 \\
\hline Early childhood & $2-5$ & 4 & 33.23 \\
\hline Late childhood & $6-9$ & 1 & 8.33 \\
\hline adolescent & $10-15$ & 6 & 50 \\
\hline
\end{tabular}

$50 \%$ of HBV infection seen in adolescent.

\begin{tabular}{|c|c|c|}
\hline $\begin{array}{c}50 \% \text { of } \mathrm{HBV} \text { infection } \\
\text { seen in adolescent }\end{array}$ & $\begin{array}{l}50 \% \text { of HBV infection } \\
\text { seen in adolescent }\end{array}$ & $\begin{array}{c}50 \% \text { of } \mathrm{HBV} \text { infection } \\
\text { seen in adolescent }\end{array}$ \\
\hline Al-Manshia & 3 & \\
\hline Al-Thanawia & 2 & \\
\hline Hi-Alkarama & 7 & \\
\hline Al-Gurtha & 7 & \\
\hline Al-Mahdia & 7 & \\
\hline Al-Katron & 2 & \\
\hline Om-Alaranib & 7 & \\
\hline Hemira & 7 & \\
\hline Murzok & - & 1 \\
\hline Obari & - & 7 \\
\hline
\end{tabular}

\section{Discussion}

Viral hepatitis caused by HBV and HCV represents a major public problem worldwide [1,2,9]. Chronic infections with $\mathrm{HBV}$ and $\mathrm{HCv}$ are the most important risk factors for the developments of HCC in humans. HBV is the primary cause of HCC in high-risk area including China and Africa, whereas in developed countries such as United States, HCV plays a more prominent role and is at least partially responsible for the increase in HCC incidence in this country [10]. In the present study, 12 cases of HBV and 2 cases of HCV out of 25 cases who represented with acute hepatitis from a total of 1877 pediatric cases were submitted. The pediatric were aged between ( $1 \mathrm{mths}-15$ years) and $50 \%$ of the patients were male and $50 \%$ females in HBV and HCV cases.

Several studies found similar results. Prevalence of HBV and HCV in the population of blood donors in Georgia has been investigated, out of 4970 donors $7 \%$ had anti- HCU $(6.9 \%$ confermed), HBsAg was positive in $4.1 \%$ (3.4\% confirmed [11].

1. Hepatitis markers (HBV and HCV) in primary school children in Freetown, Sierra Leone was investigated in a government school, 12 pupils of the 450 were positive for HBsAg (males g, females 3), while HCV were detected in one case of children [12]. In Senegal HBV is contracted at the early childhood [4].

In contrast to these studies Triki, et al. [13] showed the high prevalence of HBV infection in Tunisia, it occurs mainly in children and teenagers, and vertical and perinatal transmission of HBV does not appear to be significant. While sero-prevalence of HCV in the Tunisian general population was low $(0.4 \%)$. Among the Canadian Inuit, the prevalence of HBV infection is $5 \%$ while serological evidence of HCV infection is more common in the Canadian Inuit and first nations. 
$(1 \%-18 \%)$ than the remainder of Canadian population $(0.5 \%-2 \%)$, so viral hepatitis is common in the Canadian Inuit and first nations populations [9]. There is locally reported study by Saleh, et al. [14] finding that 21 (7.9\%) of the 266 subject had evidence of HCV infection indicates that there is a very high frequency of community - acquired "HCV in the normal Libyan population, and this has major implication for blood transfusion in that country. In the present study the geographical distribution of hepatitis cases in Sebha, South Libya were described in table 3. It is known that the prevalence of HBV and HCV infections vary according to geographical areas. However in Russia, HBV infection is widespread in Moscow and have led to a high incidence of acute and chronic liver diseases among children in this region [15].

Hepatitis is common in the Stann Greek District of Southern Belize, especially acute hepatitis B [16]. Viral hepatitis observed in Cambodia and Vietnam to improve the control measures against viral hepatitis in the public health programs [17]. In Bolivia, as in other developing countries, viral hepatitis represents a serious burden for public health [18]. As well as the prevalence of (HCV) in Libya has been investigated by seeking evidence of HCV infection in healthy Libyan subjects [14].

In this study the cases of male are equal to female in both HBV and HCV. As well as the incidence of HBV are higher than HCV, while the incidence of both HBV and HCV are low in Sebha.

Among 25 cases of acute hepatitis, 12 cases $48 \%$ where hepatitis B, and $8 \%$ where hepatitis C. although no large population study of American children is available, hepatitis B probably accounts for about $30 \%$ of cases while hepatitis C is found in approximately $20 \%$ (9) showing higher incidence of hepatitis B in Libyan children and higher incidence of hepatitis $\mathrm{C}$ in American children.

The rate of vaccination in Libya (anti-HBs) was 78.1\%, moreover, $82.6 \%$ of healthcare workers received at least one dose of the vaccine, but only $72 \%$ reported that they had received a full vaccination. The prevalence of hepatitis $\mathrm{B}$ surface antigen was $1.1 \%$. The average prevalence of hepatitis B core antibody (anti-HBc) was 17.3\%, and hospital healthcare workers were frequently exposed to blood-borne infections. Vaccines should be more readily available to Libyan healthcare workers, and current vaccination programs should be implemented [19].

\section{Conclusion and recommendation}

This study shows low incidence rates of HBV and HCV infections in Sebha city. Hepatitis is a major health hazard problem, as both viruses are potentially avoidable if hepatitis precautions rules are practiced strictly and regularly in Sebha city. Increased medical knowledge about the routes of viral infection among both doctor's staff and patients by regular educational sessions can also help in avoiding this health hazard problem. Also, active programs need to be controlled in the spreading of such infections, in the population at large. The use of viral screening programs must include and the available HBV vaccination.

While HCV Ab positive cases by ELISA, need further confirmation using PCR test and the possibility of liver biopsy as some of them may need and benefit from interferon treatment. Upon identification effective prophylaxis should be introduced and maintained.

This work was an independent collective achievement and its own results, which were the results of our efforts of collecting samples, statistical analysis and writing. We thank you for your keenness and your kind cooperation.

\section{References}

1. Attia MA. Prevalence of hepatitis B and C in Egypt and Africa. Antivir ther. 1998; 3: 1-419

2. Chandra M, Khaja MN, Faress $N$, Poduri CD, Hussain MM, et al. Prevelance, risk factors and genotypre distribution of HCV and HBV infection in trible population: A community based study in South India. Trop Gastroenterol. 2003; 24: 193-195.

PubMed: https://pubmed.ncbi.nlm.nih.gov/15164530/

3. Kiran V. Hepatitis B vaccine introduction into the routine immunization schedule Andhra Pradesh experience. Indian J Public Health. 48: 63-66.

4. Sall Diallo A, Sarr M, Fakll Y, Diagne, Mo K. hepatitis B infection in infantile population of Senegal. Darkar Med. 2004; 49: 136-142.

5. Brunett R, Francois G, Kew MC, Leroux-Roels G, Meheus A, et al. Hepatitis $B$ virus and human immunodeficiency virus co-infection in sub-Sahara Africa: a call for further investigation Liver Int. 2005; 25: 201-213.

PubMed: https://pubmed.ncbi.nlm.nih.gov/15780040/

6. Debonne JM, Nicand E, Boutin JP, Carre D, Buisson Y. Hepatitis C in tropical areas. Med Trop. 1999; 59; 508-516.

7. El Raziky MS, EL-Hawary, Elkoofy N, Okasha S, Kotb M, et al. Hepatits $\mathrm{C}$ virus infection in Egyptian children. Single center experience. J viral hepat. $2004 ; 11: 471-476$.

8. Mangoud AM, Eissa MH, Sabee El, Ibrahim IA. HCV and associated concomitant infections at Sharkia governorate, Egypt. J Egypt. Soc parasitol. 2004; 34: 447-458.

9. Minuk GY. Uhanova J. Viral hepatitis in the Candian Inuit and first nation's populations. Can J Gastroenterol. 2003; 17: 707-712.

10. Yu MC, Yuan JM. Environmental factors and risk for hepatocellular carcinoma. Gastroenterology. 2004; 127: 572-578.

11. Butsashvili M, Tsertsvadze T, MC Nutt LA, Kamkamidze G, Gvetadze R, et al. Prevalence of hepatitis B, hepatitis C, Syphilis and HIV in Georgian Blood donor. Eur J Epidemiol. 2001; 17: 693-695.

PubMed: https://pubmed.ncbi.nlm.nih.gov/12086085/

12. Hodges M, Sanders E, Aitken C. Seroprevalence of hepatitis marker; HAV, HBV, HCV and HEV amongst primary school children in Freetown, sierr leone. West Afr J Med. 1998; 17: 36-37.

13. Tirik H, Said N, Salah AB, Arrouji A, Ahmed FB, et al. Seroepidemiology of hepatitis B, C and delta viruses in Tunisia. Trans Ro Soc Trop Med Hyg. 1997; 91: 11-14.

PubMed: https://pubmed.ncbi.nlm.nih.gov/9093616/

14. Saleh MG, Pereira LM, Tibbs CJ. Ziu M, Fituri M, et al. High prevalence of hepatitis $\mathrm{C}$ virus in the normal Libayn population trans. $\mathrm{R}$ Soc. Trop. 
Med. Hyg. 1994; 88; 292-294.

PubMed: https://pubmed.ncbi.nlm.nih.gov/7974663/

15. Abe K, Hayaja E, Sminov AV, Rossina AL, Ding X, et al. Molecular epidemiology of hepatitis $B, C, D$, and $E$ viruses among children in Moscow, Russia. J Clin Virol. 2004 30: 57-61.

PubMed: https://pubmed.ncbi.nlm.nih.gov/15072755/

16. Bryan JP, Reyes L, Hahres, Gloria R, Kishore GM, et al. Epidemiology of acute hepatitis in Stann Greek district of Belize, central America. Am J Trop Med Hyg. 2001; 65: 318 -324.

PubMed: https://pubmed.ncbi.nlm.nih.gov/11693876/

17. Buchy P, Monchy D, An TT Srey CT, Tri DV, et al. Prevalence of hepatitis $A, B, C$ and $E$ viruses markers among patients with elevated levels of alanine amino transferase and aspartate amino transeferase in Phnom penh (Cambodia) and NhaTrang (Central Vietnam) Bull Soc Pathol Exot. 2004; 97: 165-171.

18. Gandolfo GM, Ferri GM, Conti G. Pprevalence of infections hepatitis $A, B, C$ and $E$ viruses in two different socioeconomic groups of children from Santa Cruz, Bolivia. Med Clin (Barc). 2003; 120: 725-727.

19. Ziglam H. El-Hattab, M. Shingheer, N. Zorgani, A. Elahmer O. Hepatitis $B$ vaccination status among healthcare workers in a tertiary care hospital in Tripoli, Libya. J Infect Public Health. 2013; 6: 246-251. PubMed: https://pubmed.ncbi.nlm.nih.gov/23806698/ 